\title{
Structural Analysis of the Cu-binding Site in the $[\mathrm{Cu} \cdot d C M P \cdot d C M P-H]^{1-}$ Complex
}

\author{
Sang-Mi Jung and Ho-Tae Kim* \\ Department of Applied Chemistry, Kumoh National Institute of Technology, Gumi 730-701, Korea
}

Received Novermber 18, 2013; Revised December 3, 2013; Accepted December 4, 2013

First published on the web December 30, 2013; DOI: 10.5478/MSL.2013.4.4.67

\begin{abstract}
The Cu-binding site in the $[\mathrm{Cu} \cdot \mathrm{dCMP} \cdot \mathrm{dCMP}-\mathrm{H}]^{1-}$ complex was investigated. The tandem mass (MS/MS) spectra of the $[\mathrm{Cu} \cdot \mathrm{dCMP} \cdot \mathrm{dCMP}-\mathrm{H}]^{-1}$ parent ion showed $\left[\mathrm{dCMP} \cdot \mathrm{Cu} \cdot \mathrm{H}_{2} \mathrm{PO}_{4}+\mathrm{CONH}\right]^{1-}$ fragment ions. Therefore, we propose that the $\mathrm{Cu}$ cation is simultaneously coordinated to the phosphate site and cytosine moiety in the stable geometry of the [Cu $\cdot \mathrm{dCMP} \cdot \mathrm{dCMP}-$ $\mathrm{H}]^{1-}$ complex. Three geometries for the complex were considered in an attempt to optimize the structure of the $[\mathrm{Cu} \cdot \mathrm{dCMP} \cdot \mathrm{dCMP}-\mathrm{H}]^{1-}$ complex. The ab initio calculations were performed at the B3LYP/6-311G** level.
\end{abstract}

Keywords: Dcmp; [Cu·dCMP·dCMP-H $]^{1-}$ complex; Mass spectrometry (MS); Tandem Mass Spectrometry (MS/MS)

\section{Introduction}

The interactions of metal cations with DNA, as a part of a [M.DNA] complex, have been studied extensively using IR, ${ }^{1}$ X-ray, ${ }^{2}$ and other techniques. ${ }^{3}$ Metal cations can both stabilize and destabilize DNA; $;^{4}$ they prefer to interact with the phosphate anions in the backbone of DNA by nonspecific electrostatic attraction, which stabilizes the DNA helix structure. ${ }^{1,5}$ However, several divalent metal cations destabilize DNA and decrease the mean transition temperature $\left(\mathrm{T}_{\mathrm{m}}\right)$ of DNA. ${ }^{4}$ In particular, $\mathrm{Cu}$ cations substantially decrease the $\mathrm{T}_{\mathrm{m}}$ of DNA. ${ }^{4} \mathrm{Cu}$ cations are regarded to be effective in destroying the native structure of DNA. In contrast to $\mathrm{Cu}$ cations, $\mathrm{Mg}$ cations increase the $T_{m}$ of DNA and stabilize DNA.

The structures of [M-(nucleoside monophosphate)] complexes have been investigated to evaluate the effect of metal cations on the structure of the [M.DNA] complex. ${ }^{6-11}$ Metal cations prefer the phosphate anions; however, several experimental results showed that the base moieties had also been regarded as the preferred binding sites in the formation of [M.(nucleoside monophosphate)] complexes. As a member of [M.(nucleoside monophosphate)] comp-

\section{Open Access}

*Reprint requests to Dr. Ho-Tae Kim

E-mail: hotaekim@kumoh.ac.kr

All MS Letters content is Open Access, meaning it is accessible online to everyone, without fee and authors' permission. All MS Letters content is published and distributed under the terms of the Creative Commons Attribution License (http://creativecommons.org /licenses/by/3.0/). Under this license, authors reserve the copyright for their content; however, they permit anyone to unrestrictedly use, distribute, and reproduce the content in any medium as far as the original authors and source are cited. For any reuse, redistribution, or reproduction of a work, users must clarify the license terms under which the work was produced. lexes, $[\mathrm{M} \cdot \mathrm{dCMP}](\mathrm{dCMP}=$ deoxycytidine monophosphate $)$ complexes have been extensively studied. ${ }^{7-11}$ A local pentacoordinated tetragonal pyramid geometry with a coordination of one $\mathrm{N}$ atom (cytosine) and four $\mathrm{O}$ atoms has been observed by the powder EPR spectrum of [Cu.CMP] complex. ${ }^{7}$ The metal binding sites of the $[\mathrm{M} \cdot \mathrm{H} \cdot \mathrm{dCMP}]^{1+}\left(\mathrm{M}=\mathrm{Mg}^{2+}, \mathrm{Cu}^{2+}\right)$ complex has been observed in the aqueous solution; ${ }^{10}$ the metal cation was mainly located at the N3 (cytosine) atom, as determined by the acidity constant analysis using potentiometric $\mathrm{pH}$ titrations. However, the coordination chemistry between $\mathrm{Cu}$ cation and nucleic acid building block such as nucleotides, is rather scarcely documented in gas-phase.

In this study, we have focused our attention on the formation and fragmentation pattern of gas-phase $[\mathrm{dCMP}]^{1-}$ and $[\mathrm{M} \cdot \mathrm{dCMP} \cdot \mathrm{dCMP}-\mathrm{H}]^{1-}\left(\mathrm{M}=\mathrm{Mg}^{2+}, \mathrm{Cu}^{2+}\right)$ complexes using ESI-MS and tandem mass spectrometry (MS/MS) methods. The $[\mathrm{dCMP}]^{1-}$ and $[\mathrm{M} \cdot \mathrm{dCMP} \cdot \mathrm{dCMP}-\mathrm{H}]^{1-}$ complexes were formed in the solution and electrosprayed on the quadrupole ion guide using nitrogen gas. Intact gas-phase $[\mathrm{dCMP}]^{1-}$ and $[\mathrm{M} \cdot \mathrm{dCMP} \cdot \mathrm{dCMP}-\mathrm{H}]^{1-}$ complex ions were expected in the ESI-MS spectra. ${ }^{12-14}$ An Ab initio calculation was performed to explain the geometry and stabilization energy of the $[\mathrm{Cu} \cdot \mathrm{dCMP} \cdot \mathrm{dCMP}-\mathrm{H}]^{1-}$ complex ion.

\section{Experimental}

Intact gas-phase $[\mathrm{dCMP}]^{1-}$ or $[\mathrm{M} \cdot \mathrm{dCMP} \cdot \mathrm{dCMP}-\mathrm{H}]^{1-}$ $\left(\mathrm{M}=\mathrm{Mg}^{2+}, \mathrm{Cu}^{2+}\right)$ ion was formed by the ESI-MS method. The experimental MS and MS/MS data for the fragmentation pattern analysis were obtained using a Thermo Finnigan LTQ mass spectrometer (Thermo Electron Corporation, San Jose, CA, USA). The LTQ mass spectrometer conditions have been reported in the previous study. ${ }^{15}$ 


\section{Reagents}

The reagents used are as follows: dCMP (2'-deoxycytidine 5'-monophosphate 98\%, Sigma-Aldrich, Korea), $\mathrm{CuCl}_{2}$ (99.999\%, Sigma-Aldrich, Korea), $\mathrm{MgCl}_{2}$ (99.99\%, SigmaAldrich, Korea), $\mathrm{H}_{2} \mathrm{O}$ (HPLC grade, Merck), and $\mathrm{D}_{2} \mathrm{O}$ (99.9 atom $\%$, Sigma-Aldrich, Korea). dCMP was dissolved in $\mathrm{H}_{2} \mathrm{O}$ ( or $\mathrm{D}_{2} \mathrm{O}$ ) to prepare a $4 \times 10^{-5} \mathrm{M}$ solution. $\mathrm{CuCl}_{2}$ was dissolved in $\mathrm{H}_{2} \mathrm{O}$ (or $\mathrm{D}_{2} \mathrm{O}$ ) to prepare a $4 \times 10^{-4} \mathrm{M}$ solution. The $[\mathrm{dCMP}+$ metal] solutions were mixed prior to the mass spectral analyses.

\section{Computational Methods}

The $a b$ initio calculations were performed using $6-311 \mathrm{G}^{* *}$ basis sets to determine the optimized structures and energies. The density functional theory (DFT) calculations at the B3LYP level were carried out using the Gaussian09 series program. DFT was chosen because it is less computationally demanding than the other computational methods with a similar accuracy for the ground-state energy calculations. ${ }^{16}$ The vibrational frequencies were also calculated at the B3LYP level to confirm the optimized geometries corresponding to the true minima on the potential energy surface.

\section{Results and discussion}

The structures of $[\mathrm{dCMP}]^{1-}$ and three $[\mathrm{Cu} \cdot \mathrm{dCMP} \cdot \mathrm{dCMP}-$ $\mathrm{H}]^{1-}$ complexes are shown in Fig. 1. A copper ion is located in the center of two dCMP molecules because of the basicity of the corresponding phosphate groups. Complexes 1 and 2 show a square planar geometry, where the $\mathrm{Cu}$ cation is tetracoordinated to the four $\mathrm{O}$ atoms in Complex 1, or two $\mathrm{O}$ and two $\mathrm{N}$ atoms in Complex 2. Complex 3 showed a tetragonal pyramid geometry, where the $\mathrm{Cu}$ cation is penta-coordinated to the five $\mathrm{O}$ atoms. The $\mathrm{N} 3$ atom of cytosine in dCMP is indicated as a part of the $[\mathrm{Cu} \cdots \mathrm{dCMP}]$ coordination in Fig. 1c.

Four MS/MS spectra are shown in Fig. 2. In the MS/MS spectrum of $[\mathrm{dCMP}]^{1-}$ ion (Fig. 2a), the fragment ions at $\mathrm{m} / \mathrm{z}$ 263, 195, and 97 were observed under the low-energy CID experimental conditions. The ions at $m / z 263$ and 195 were assigned to the loss of $\mathrm{CONH}$ and cytosine fragments in the parent $[\mathrm{dCMP}]^{1-}$ ion, respectively. The low-energy CID MS/ MS results of the four parent ions are summarized in Table 1. The CONH loss dissociation channel of the $[\mathrm{dCMP}]^{1-}$ ion is indicated as the ' $\mathrm{B}$ ' bond dissociation in Fig. 1a. The CONH loss dissociation channel of the cytosine part has been reported in the MS/MS spectrum of the $[\mathrm{Cu} \cdot \mathrm{Cyt} \cdot \mathrm{Gua}-\mathrm{H}]^{1+}$ ion. ${ }^{15}$ The fragment ion at $m / z 97$ was assigned to a $[306-\mathrm{dC}+18]^{1-}$ ion, which corresponded to a $\left[\mathrm{H}_{2} \mathrm{PO}_{4}\right]^{1-}$ ion. The added 18 amu may be attributed to the (OH group $+\mathrm{H}$ atom), able to be associated to the $\mathrm{PO}_{3}$ group. The formation of the fragment ion at $m / z 97$ may be alternatively caused by the 'Al' bond dissociation (Fig. 1a). The fragment ion at $m / z 97$ in this dissociation process may be attributed to a $[306-(\mathrm{dC}-$ $\mathrm{O})+2 \mathrm{H}]^{1-}$ ion, which still corresponded to a $\left[\mathrm{H}_{2} \mathrm{PO}_{4}\right]^{1-}$ ion. The $(\mathrm{OH}$ group $+\mathrm{H}$ atom $)$ dissociation process from the phosphate group has been reported by Strittmatter et al. ${ }^{17}$

The MS/MS spectrum of the $[\mathrm{Mg} \cdot \mathrm{dCMP} \cdot \mathrm{dCMP}-\mathrm{H}]^{1-}$ complex $(m / z 635)$ shows two main fragments, $m / z 306$ and 408 , corresponding to a $[\mathrm{dCMP}]^{1-}$ ion and a dC-loss fragment ion, respectively, as shown in Fig. 2b. Each dissociation channel is indicated as the ' $D$ ' or ' $E$ ' bond dissociation in Fig. 2b. A fragment ion at $m / z 425$, a $[635-\mathrm{dC}+18]^{1-}$ ion, which was observed in a low intensity corresponded to a $\left[\mathrm{dCMP} \cdot \mathrm{Mg} \cdot \mathrm{H}_{2} \mathrm{PO}_{4}\right]^{1-}$ ion. Two fragment ions, [306$\mathrm{dC}+18]^{1-}$ ion (Fig. 2a) and $[635-\mathrm{dC}+18]^{1-}$ ion (Fig. 2b),
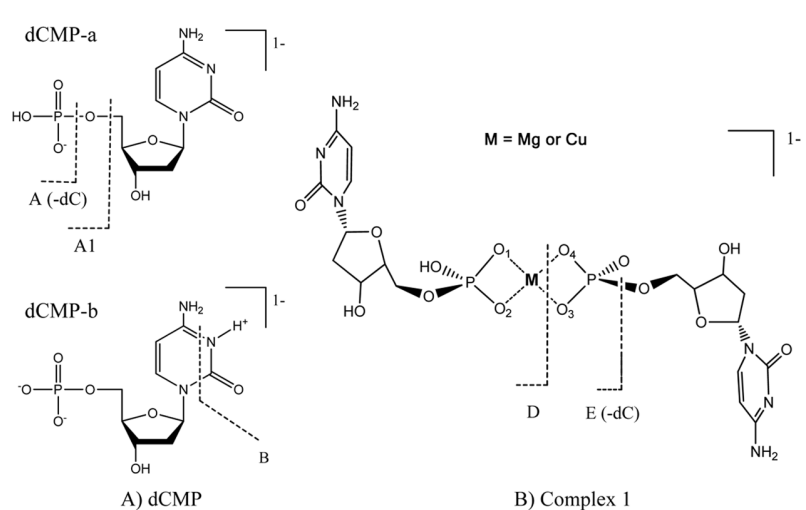

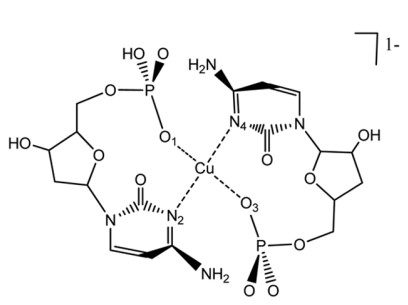

C) Complex 2

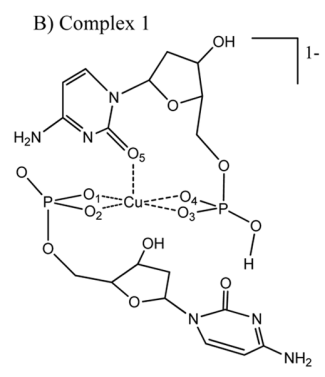

D) Complex 3
Figure 1. Structures of $[\mathrm{dCMP}]^{1-}$ and $[\mathrm{Cu} \cdot \mathrm{dCMP} \cdot \mathrm{dCMP}-\mathrm{H}]^{1-}$ complexes.

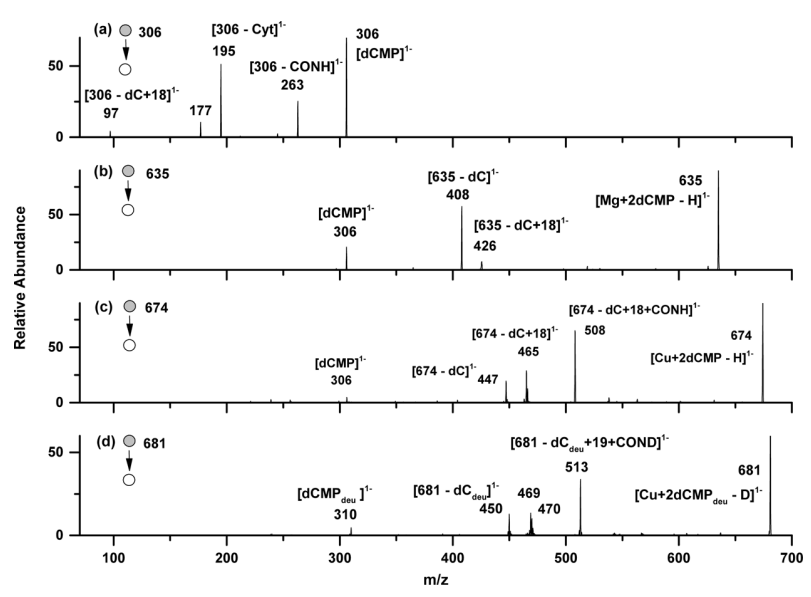

Figure 2. ESI-MS/MS spectra of (a) $[\mathrm{dCMP}]^{1-}$, (b) $[\mathrm{Mg}+2 \mathrm{dCMP}-$ $\mathrm{H}]^{1-}$, (c) $[\mathrm{Cu}+2 \mathrm{dCMP}-\mathrm{H}]^{1-}$, and (d) $\left[\mathrm{Cu}+2 \mathrm{dCMP}_{\text {deu }}-\mathrm{D}\right]^{1-}$ parent ion. 
may have originated from a similar dissociation process. Based on the observation in Fig. 2b, Complex 1 geometry (dCMP...Mg $\cdots \mathrm{dCMP}$ ) should be regarded as a stable geometry in the $[\mathrm{Mg} \cdot \mathrm{dCMP} \cdot \mathrm{dCMP}-\mathrm{H}]^{1-}$ complex. $^{18}$

Fig. 2c shows the MS/MS spectrum of the parent $[\mathrm{Cu} \cdot \mathrm{dCMP} \cdot \mathrm{dCMP}-\mathrm{H}]^{1-}(\mathrm{m} / \mathrm{z} 674)$ ion. Interestingly, a [674$\mathrm{dC}+18+\mathrm{CONH}]^{1-}$ fragment ion at $m / z 508$ was observed, which corresponded to the $\left[\mathrm{dCMP} \cdot \mathrm{Cu} \cdot \mathrm{H}_{2} \mathrm{PO}_{4}+\mathrm{CONH}\right]^{1-}$ ion. This dissociation channel of the cytosine CONH moiety (' $\mathrm{B}$ ' in Fig. 1a) was not observed in the MS/MS spectrum of the $[\mathrm{Mg} \cdot \mathrm{dCMP} \cdot \mathrm{dCMP}-\mathrm{H}]^{1-}$ ion (Fig. 2b). Therefore, the $\mathrm{CONH}$ moiety may be associated to the central $\mathrm{Cu}$ cation in the $[\mathrm{Cu} \cdot d C M P \cdot d C M P-H]^{1-}$ complex. For the analysis of the association of the $\mathrm{CONH}$ moiety $(+\mathrm{CONH})$ to the $[674-$ $\mathrm{dC}+18]^{1-}$ fragment, the geometry of Complex 2 or 3 was proposed as the stable structure for the $[\mathrm{Cu} \cdot d C M P \cdot d C M P-$ $\mathrm{H}]^{1-}$ ion (Fig. 1). The cytosine $\mathrm{N} 3$ or $\mathrm{O} 2$ atom was indicated as the participating ligand in the $[\mathrm{Cu} \cdots \mathrm{dCMP}]$ coordination in the geometry of Complex 2 or 3 . The participation of cytosine $\mathrm{N} 3$ atom in the $[\mathrm{Cu} \cdots \mathrm{dCMP}]$ coordination has been proposed by the powder EPR spectrum of the $\mathrm{Cu}-5$ '-CMP complex. ${ }^{11}$ The participation of cytosine $\mathrm{N} 3$ or $\mathrm{O} 2$ atom in the [metal $\cdots \mathrm{dCMP}]$ coordination structure has also been analyzed in the structure of the $[\mathrm{Pb} \cdot \mathrm{dCMP}-\mathrm{H}]^{1+}$ complex. $^{11}$

Other main MS/MS fragment ions of the parent [Cu.dCMP.dCMP-H] $]^{1-}(\mathrm{m} / \mathrm{z}$ 674) ion were observed at $\mathrm{m} / \mathrm{z}$ 465,447 , and 306 corresponding to $[674-\mathrm{dC}+18]^{1-}$, [674$\mathrm{dC}]^{1-}$, and $[\mathrm{dCMP}]^{1-}$, respectively (Fig. 2c). These fragment ion analysis was supported by a $\mathrm{D}_{2} \mathrm{O}$ experiment from the observation of $\mathrm{m} / \mathrm{z} 469$ (470), 450, and 310 corresponding to $\left[681-\mathrm{dC}_{\mathrm{deu}}+19\right]^{1-}\left(\left[681-\mathrm{dC}_{\mathrm{deu}}+20\right]^{1-}\right),\left[681-\mathrm{dC}_{\mathrm{deu}}\right]^{1-}$, and $\left[\mathrm{dCMP}_{\mathrm{deu}}\right]^{1-}$, respectively (Fig. 2d). Seven possible hydrogen atoms existed, as shown in Complex 2 or 3 , for the $\mathrm{H} / \mathrm{D}$ deuteration process in the $[\mathrm{Cu} \cdot \mathrm{dCMP} \cdot \mathrm{dCMP}-\mathrm{H}]^{1-}(\mathrm{m} / \mathrm{z}$ 674) complex. Therefore, the $\left[\mathrm{Cu} \cdot \mathrm{dCMP}_{\mathrm{deu}} \cdot \mathrm{dCMP}_{\mathrm{deu}}-\mathrm{D}\right]^{1-}$ $(\mathrm{m} / z$ 681) ion was selected as the parent ion in the MS/MS spectrum (Fig. 2d). The peak at $m / z 513$ was assigned as a $\left[681-\mathrm{dC}_{\mathrm{deu}}+19+\mathrm{COND}\right]^{1-}$ ion (Table 1$)$ because of the higher intensity of $m / z 469\left(\left[681-\mathrm{dC}_{\mathrm{deu}}+19\right]^{1-}\right.$ ion $)$ than that of $m / z 470$ ([681- $\left.\mathrm{dC}_{\mathrm{deu}}+20\right]^{1-}$ ion) (Fig. $\left.2 \mathrm{~d}\right)$.

In order to know the stability of the $[\mathrm{Cu} \cdot \mathrm{dCMP} \cdot \mathrm{dCMP}-\mathrm{H}]^{1-}$ complex ion, we tried to optimize the geometries of Complexes $1-3$ by the $a b$ initio calculations. The relative SCF energies for Complexes 1-3 are listed in Table 2, as the energy difference from Complex 1. The energy differences were in a -15.4 to $10.1 \mathrm{kcal} / \mathrm{mol}$ range based on the gas-phase B3LYP/6-311G** calculations. Complex 2 was the most stable structure among the optimized $[\mathrm{Cu} \cdot \mathrm{dCMP} \cdot \mathrm{dCMP}-\mathrm{H}]^{1-}$ complexes. Three structures (Complex 1-3) may have been formed simultaneously in $(\mathrm{Cu}+\mathrm{dCMP})$ solution in conformity to the similar $\mathrm{SCF}$ energies of the three $[\mathrm{Cu} \cdot \mathrm{dCMP} \cdot \mathrm{dCMP}-\mathrm{H}]^{1-}$ optimized complexes. Similarly, the negative charge character of the cytosine N3 atom can be compared to that of the phosphate group $\mathrm{O}$ atom in the $[\mathrm{dCMP}]^{1-}$ ion. In the geometry optimized $[\mathrm{dCMP}]^{1-}$ ion, the atomic charges (phosphate group $\mathrm{O}$ atoms, cytosine $\mathrm{N} 3$, and cytosine $\mathrm{O} 2$ ) were calculated in the range from -0.7 to -0.4 (Table 3 ).

Table 1. Fragment ions in MS/MS spectra of Figs. $2 \mathrm{a}-2 \mathrm{~d}$

\begin{tabular}{|c|c|c|}
\hline Parent ion & $\begin{array}{l}\text { Fragment } \\
\text { ion } \\
(\mathrm{m} / \mathrm{z})\end{array}$ & Assignment \\
\hline \multirow{4}{*}{ 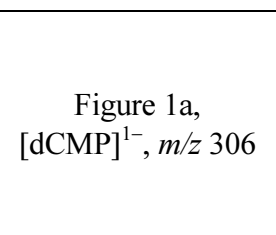 } & 263 & {$[306-\mathrm{CONH}]^{1-}$} \\
\hline & 195 & {$[306-\mathrm{Cyt}]^{1-}$} \\
\hline & 177 & {$[306-\mathrm{Cyt}-18]^{1-}$} \\
\hline & 97 & $\begin{array}{c}{\left[306-\mathrm{dC}^{\mathrm{a}}+18\right]^{1-} \text { or }} \\
{\left[\mathrm{H}_{2} \mathrm{PO}_{4}\right]^{1-}}\end{array}$ \\
\hline \multirow{3}{*}{$\begin{array}{c}\text { Figure } 1 \mathrm{~b}, m / z 635 \\
{[\mathrm{Mg}+2 \mathrm{dCMP}-\mathrm{H}]^{1-}}\end{array}$} & 426 & $\begin{array}{l}{[635-\mathrm{dC}+18]^{1-} \text { or }} \\
{\left[\mathrm{dCMP} \cdot \mathrm{Mg} \cdot \mathrm{H}_{2} \mathrm{PO}_{4}\right]^{1-}}\end{array}$ \\
\hline & 408 & {$[635-\mathrm{dC}]^{1-}$} \\
\hline & 306 & {$[\mathrm{dCMP}]^{1-}$} \\
\hline \multirow{4}{*}{$\begin{array}{c}\text { Figure 1c } \\
{\left[\begin{array}{c}{[\mathrm{Cu}+2 \mathrm{dCMP}-\mathrm{H}]^{1-},} \\
m / z 674\end{array}\right.}\end{array}$} & 508 & $\begin{array}{c}{\left[(674-\mathrm{dC}+18+\mathrm{CONH}]^{1-}\right.} \\
\quad \text { or }\left[\mathrm{dCMP} \cdot \mathrm{Cu} \cdot \mathrm{H}_{2} \mathrm{PO}_{4}+\right. \\
\mathrm{CONH}]^{1-}\end{array}$ \\
\hline & 465 & {$[674-\mathrm{dC}+18]^{1-}$} \\
\hline & 447 & {$[674-\mathrm{dC}]^{1-}$} \\
\hline & 306 & {$[\mathrm{dCMP}]^{1-}$} \\
\hline \multirow{5}{*}{$\begin{array}{c}\text { Figure } 1 \mathrm{~d}, \\
{\left[\mathrm{Cu}+2 \mathrm{dCMP}_{\mathrm{deu}}-\right.} \\
\mathrm{D}^{1-} \\
m / z 681\end{array}$} & 513 & $\begin{array}{c}{\left[681-\mathrm{dC}_{\mathrm{deu}}^{\mathrm{b}}+19+\right.} \\
\mathrm{COND}]^{1-}\end{array}$ \\
\hline & 470 & {$\left[681-\mathrm{dC}_{\mathrm{deu}}+20\right]^{1-}$} \\
\hline & 469 & {$\left[681-\mathrm{dC}_{\mathrm{deu}}+19\right]^{1-}$} \\
\hline & 450 & {$\left[681-\mathrm{dC}_{\mathrm{deu}}\right]^{1-}$} \\
\hline & 310 & {$\left[\mathrm{dCMP}_{\mathrm{deu}}\right]^{1-}$} \\
\hline
\end{tabular}

adC (deoxycytidine $)=$ Cytosine + deoxyribose

${ }^{b} \mathrm{dC}_{\mathrm{deu}}=[\mathrm{dC}+4 \mathrm{H} / \mathrm{D}], \mathrm{dCMP}_{\mathrm{deu}}=[\mathrm{dCMP}+4 \mathrm{H} / \mathrm{D}]$

Table 2. SCF energies of three optimized $[\mathrm{Cu} \cdot \mathrm{dCMP} \cdot \mathrm{dCMP}-$ $\mathrm{H}]^{1-}$ complex ions in B3LYP/6-311G** calculations

\begin{tabular}{ccc}
\hline \hline & \multicolumn{2}{c}{ SCF Energy (gas-phase) } \\
\cline { 2 - 3 } & $\begin{array}{c}\text { B3LYP/6-311G** } \\
\text { (hartree) }\end{array}$ & $\begin{array}{c}\Delta^{\mathrm{a}} \\
(\mathrm{kcal} / \mathrm{mol})\end{array}$ \\
\hline Complex 1 & -4406.74578619 & 0.0 \\
Complex 2 & -4406.77031917 & -15.4 \\
Complex 3 & -4406.76194496 & -10.1 \\
\hline
\end{tabular}

${ }^{\mathrm{a}}$ Energy difference $=$ Energy $($ Complex $\mathrm{n})-$ Energy $($ Complex 1)

Table 3. Atomic charge distributions of optimized [dCMP $]^{1-}$ ion

\begin{tabular}{ccc}
\hline \hline Atom & & Charge distribution \\
\hline \multirow{3}{*}{ Phosphate group } & $\mathrm{O}$ & -0.71 \\
& $\mathrm{O}$ & -0.63 \\
& $\mathrm{O}$ & -0.57 \\
$\mathrm{O}$ & -0.55 \\
Cytosine & $\mathrm{N} 3$ & -0.41 \\
& $\mathrm{O} 2$ & -0.41 \\
\hline
\end{tabular}

Mass Spectrom. Lett. 2013 Vol. 4, No. 4, 67-70 
Table 4. Optimized geometric parameters of $[\mathrm{Cu} \cdot d C M P \cdot d C M P-$ $\mathrm{H}]^{1-}$ complex ions in B3LYP/6-311G** calculations

\begin{tabular}{|c|c|c|c|c|c|}
\hline & \multicolumn{5}{|c|}{ Bond distance $(\AA)$} \\
\hline & $\mathrm{O}_{1}-\mathrm{Cu}$ & $\begin{array}{c}\mathrm{O}_{2}-\mathrm{Cu}\left(\mathrm{N}_{2}-\right. \\
\mathrm{Cu})\end{array}$ & $\mathrm{O}_{3}-\mathrm{Cu}$ & $\begin{array}{c}\mathrm{O}_{4^{-}} \mathrm{Cu}\left(\mathrm{N}_{4^{-}}\right. \\
\mathrm{Cu})\end{array}$ & $\mathrm{O}_{5}-\mathrm{Cu}$ \\
\hline Complex 1 & 1.928 & 1.922 & 2.093 & 2.089 & \\
\hline Complex 2 & 1.914 & 2.068 & 1.995 & 1.974 & \\
\hline \multirow[t]{3}{*}{ Complex 3} & 1.957 & 1.978 & 2.094 & 2.196 & 2.422 \\
\hline & \multicolumn{5}{|c|}{ Dihedral angle $\left(^{\circ}\right)$} \\
\hline & \multicolumn{3}{|c|}{$\mathrm{O}_{1}-\mathrm{O}_{2}-\mathrm{O}_{3}-\mathrm{O}_{4}$} & \multicolumn{2}{|c|}{$\mathrm{O}_{1}-\mathrm{O}_{2}-\mathrm{O}_{3}-\mathrm{Cu}$} \\
\hline \multicolumn{2}{|l|}{ Complex 1} & \multicolumn{2}{|l|}{-0.4} & \multicolumn{2}{|l|}{1.3} \\
\hline \multicolumn{2}{|l|}{ Complex 2} & \multicolumn{2}{|l|}{-4.4} & \multicolumn{2}{|l|}{-6.2} \\
\hline \multicolumn{2}{|l|}{ Complex 3} & \multicolumn{2}{|l|}{-12.9} & \multicolumn{2}{|l|}{12.0} \\
\hline
\end{tabular}

The planar geometries $\left(\mathrm{Cu}-\mathrm{O}_{1} \mathrm{O}_{2} \mathrm{O}_{3} \mathrm{O}_{4}\right.$ for Complex $1, \mathrm{Cu}-$ $\mathrm{O}_{1} \mathrm{~N}_{2} \mathrm{O}_{3} \mathrm{~N}_{4}$ for Complex 2, and $\mathrm{Cu}-\mathrm{O}_{1} \mathrm{O}_{2} \mathrm{O}_{3} \mathrm{O}_{4}$ for Complex 3) were observed for the small dihedral angles in the geometry optimization of the $[\mathrm{Cu} \cdot \mathrm{dCMP} \cdot \mathrm{dCMP}-\mathrm{H}]^{1-}$ complex. The optimized parameters such as bond distances and dihedral angles are listed in Table 4. The dihedral angles, $\mathrm{O}_{1}-\mathrm{O}_{2}-\mathrm{O}_{3}-\mathrm{O}_{4}$ $\left(-0.4^{\circ}\right)$ for Complex 1 and $\mathrm{O}_{1}-\mathrm{N}_{2}-\mathrm{O}_{3}-\mathrm{N}_{4}\left(-4.4^{\circ}\right)$ for Complex 2 , were almost zero. The structure of complex $3(\mathrm{Cu}-$ $\mathrm{O}_{1} \mathrm{O}_{2} \mathrm{O}_{3} \mathrm{O}_{4} \mathrm{O}_{5}$ ) was optimized to a tetragonal pyramidal geometry (Fig. 1d). A fifth ligand (the cytosine $\mathrm{O} 2$ atom, $\mathrm{O}_{5}$ ) was added to the four-coordination $\left(\mathrm{Cu}-\mathrm{O}_{1} \mathrm{O}_{2} \mathrm{O}_{3} \mathrm{O}_{4}\right)$ geometry in the tetragonal pyramidal geometry. The carbonyl oxygen atom $\left(\mathrm{O}_{5}\right)$ of cytosine was located at the apex of the optimized tetragonal pyramidal geometry. A small deviation from the planar structure of Complex 3 was observed in the dihedral angles, $\mathrm{O}_{1}-\mathrm{O}_{2}-\mathrm{O}_{3}-\mathrm{O}_{4}\left(-12.9^{\circ}\right)$ and $\mathrm{O}_{1}-\mathrm{O}_{2}-\mathrm{O}_{3}-\mathrm{Cu}\left(12.0^{\circ}\right)$ (Table 4).

\section{Conclusions}

The Cu-binding site in the $[\mathrm{Cu} \cdot \mathrm{dCMP} \cdot \mathrm{dCMP}-\mathrm{H}]^{1-}$ complex was investigated. In the MS/MS spectrum of the $[\mathrm{Cu} \cdot \mathrm{dCMP} \cdot \mathrm{dCMP}-\mathrm{H}]^{1-}$ complex, the $\left[\mathrm{dCMP} \cdot \mathrm{Cu} \cdot \mathrm{H}_{2} \mathrm{PO}_{4}\right.$ $+\mathrm{CONH}]^{1-}$ fragment ion was observed as the main fragment ion. Based on the direct interaction between the $\mathrm{Cu}$ cation and $\mathrm{CONH}$ in the $\left[\mathrm{dCMP} \cdot \mathrm{Cu} \cdot \mathrm{H}_{2} \mathrm{PO}_{4}+\mathrm{CONH}\right]^{1-}$ fragment ion, we proposed that the $\mathrm{Cu}$ cation is bound simultaneously to the cytosine ( $\mathrm{N} 3$ or $\mathrm{O} 2)$ and a phosphate group. The simultaneous coordination of $\mathrm{Cu}$ cation to the phosphate site and cytosine moiety (Complex 2 or 3) was supported by the SCF energy calculations of the geometry optimized $[\mathrm{Cu} \cdot \mathrm{dCMP} \cdot \mathrm{dCMP}-$ $\mathrm{H}]^{1-}$ complexes.

\section{Acknowledgements}

This study was supported by Research Fund, Kumoh National Institute of Technology.

\section{References}

1. Andrushchenko, V.; Van De Sande, J. H.; Wieser, H. Biopolymers 2003, 72, 374.

2. Gao, Y.-G.; Sriram, M.; Wang, A. H.-J. Nucleic Acids Res. 1993, 21, 4093.

3. Liu, J.; Lu, T. B.; Deng, H.; Ji, L. N.; Qu, L. H.; Zhou, H. Transition Met. Chem. 2003, 28, 116.

4. Eichhorn, G. L. Nature 1962, 194, 474.

5. Atwell, S.; Meggers, E.; Spraggon, G.; Schultz, P. G. J. Am. Chem. Soc. 2001, 123, 12364.

6. Andrushchenko, V. Bour, P. J. Phys. Chem. B, 2009, 113, 283.

7. Fuente, M.; Cozar, O.; David, L.; Navarro, R.; Hernanz, A.; Bratu, I. Spectrochim. Acta part A 1997, 53, 637.

8. Aoki, K. Biochim. Biophys. Acta 1976, 447, 379.

9. Terron, A. Comments Inorg. Chem. 1993, 14, 63.

10. Song, B.; Feldmann, G.; Bastian, M.; Lippert, B.; Sigel, H. Inorg. Chim. Acta 1995, 235, 99.

11. Salpin, J.-Y.; Gamiette, L.; Tortajada, J.; Besson, T.; Maitre, P. Int. J. Mass Spectrom. 2011, 304, 154.

12. Gao, Y.-G. ; Sriram, M.; Wang, A. H. -J. Nucleic Acids Res. 1993, 21, 4093.

13. Blažiè, B.; Turel, I.; Bukovec, N.; Bukovec, P.; Lazarini, F. J. Inorg. Biochem. 1993, 51, 737.

14. Liu, J.; Lu, T. B.; Deng, H.; Ji, L. N.; Qu, L. H.; Zhou, H. Transition Met. Chem. 2003, 28, 116.

15. Kim, M.-J.; Kim, B.-R.; Kim, H.-T. Chem. Phys. Lett. 2011, 505, 57.

16. Sousa, S. F.; Fernandes, P. A.; Ramos, M. J. J. Phys. Chem. A 2007, 111, 10439.

17. Strittmatter, E. F.; Schnier, P. D.; Klassen, J. S.; Williams, E. R. J. Am. Soc. Mass Spectrom. 1999, 10, 1095.

18. Luck, G.; Zimmer, C. Eur. J. Biochem. 1972, 29, 528. 